\title{
Caribbean Visual Arts, Social Media and Performance
}

Wendy Adeliyi

The photographic installation created by María Magdalena Campos-Pons in De las dos Aguas (Between Two Waters), Campos-Pons takes the viewer on a historical journey of the two bodies of ocean water that separate Africa and the Americas. Many dualities are seen in the photo, starting with the two women standing on either side of the photograph holding opposites ends of a boat.

María Magdalena Campos-Pons in De las dos Aguas (Between Two Waters)
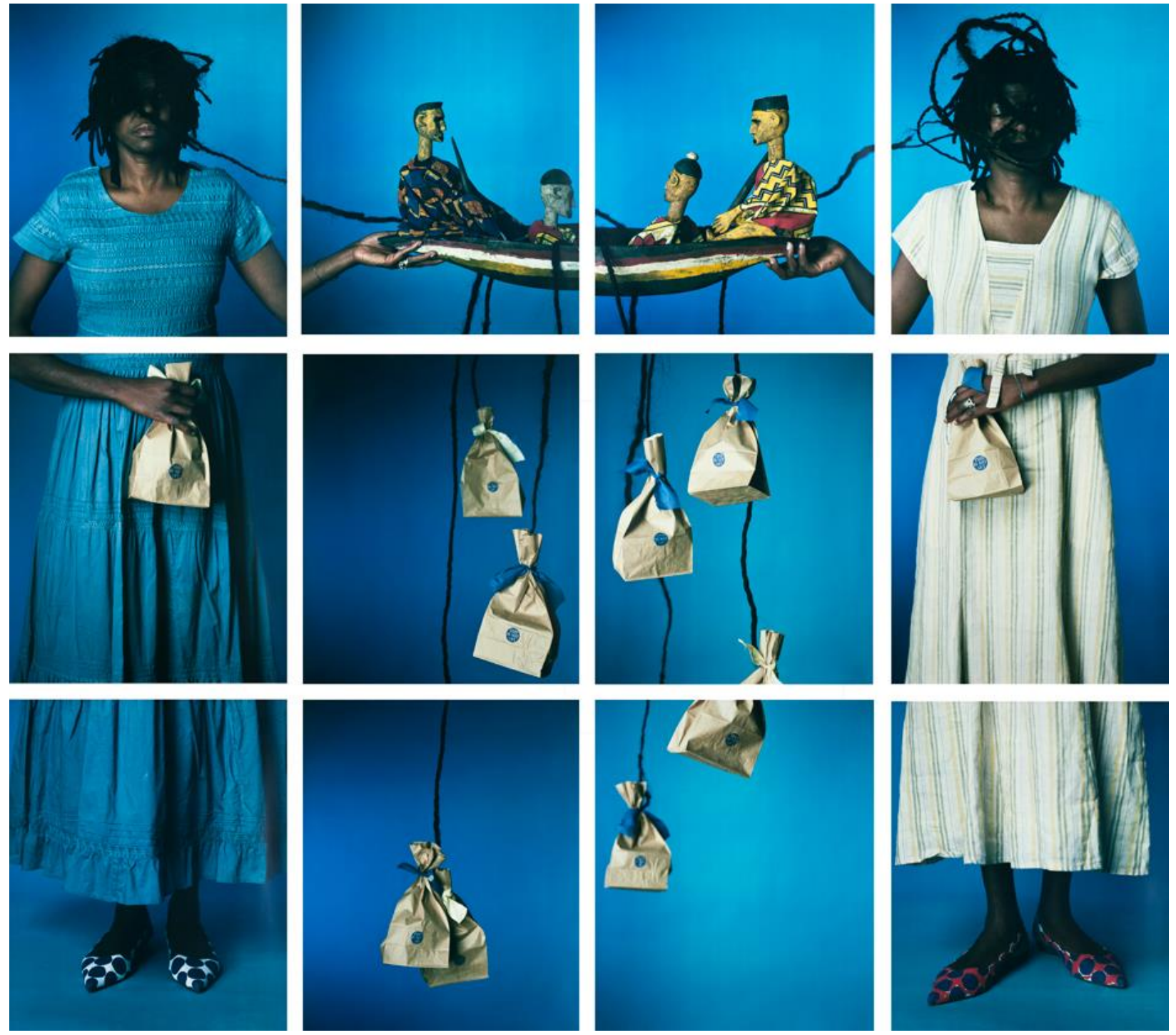

The boat in the picture is held up like a bridge to symbolize the connection between the two worlds that are separate but almost replicate each other while relying on each other for balance ( $\mathrm{C} \&$ America Latina). The artist herself is the subject of the image of the two women 
masked by dreadlocks in a sea of confusion between the worlds. The dreadlocks, acting as the masks, can be seen as protection from the brutality faced by Africans when forcefully being removed from the continent, as well as the preservation of cultural identity forcibly stripped from enslaved peoples. The dreadlocked masks can also symbolize black diaspora peoples wearing an invisible mask in Western civilization as a way to survive, but never feeling like they belong to any nation: far removed from the cultural identity of being African and not belonging to the New World colonized by whites; forever floating in a state of limbo while pain stays buried under the mask (Fanon 93). One mask covers the eyes in the ocean symbolizing the enslaved people that did not know where they were or where they were being taken to as if being led blind. The other mask on land covers the mouth representing freedom and identity lost through language (Fanon 25). Many of the enslaved were from different tribes, spoke different dialects, and could not communicate at first arrival to the New World until new creolized languages formed between each other, the Indigenous people of the Caribbean, and European settlers. Verbal selfexpression towards slave masters was forbidden but keeping one's mouth closed for survival was encouraged by fellow slaves and also brutally enforced by masters.

The story of the Slave Trade becomes visualized through the garments on the women. One woman is dressed in a blue dress and represents the ocean's Middle Passage while the other woman wears white representing the white sands of the Caribbean in the New World; both natural elements hold up the boat that floats between them. The vessel carries four male Yoruba deities from Africa bringing across the protection of the Orisha, an African ritual that offers a way to harmonize the spiritual and worldly aims through personal guardians of energy $(\mathrm{C} \&$ America Latina). Attached to the boat by stands of dreadlocks are bags of offerings from the Orisha Gods that journey to the New World with the enslaved and connect them to their dead ancestors. In Ifa philosophy, there are seven Orisha masters. Osun is the representative of sweet waters, love, money, and conception. Sango is the warrior serving thunder and lightning, along with strategy. Esu is the owner of roads and opportunities and provides spiritual energy. Yemonja/Olukun represents the ocean, mothers, and is the provider of wealth. Obatala represents the head and clarity, and is the arbiter of justice. Oya is the female warrior who embodies the marketplace, tornadoes, change in fortune, honor, and integrity (Neimark 14). The African worship helps to guide the dead ancestors, which help to guide the living by tying the past, present, and future together for the betterment of the world.

The images of the two women in the photograph both have a bag in their hand as if the offering journeyed from one continent to the other to ensure the survival of the Africans. Africans continue to survive on different continents throughout the world as migration continues in the present day, but the brutality and slaughter of African descendants continue. The woman in the ocean and dressed in blue wear blue and rich in colour with white spotted shoes represents the capture of the pure-blooded traditional African journeying across the Atlantic seas. The woman on the right dressed in white represents a washing of the culture and traditions, but her shoes are now painted in red to symbolize bloodshed from slaughter and exploitation of the African body.

The artist chooses women to be dominant in this photo and over the ocean and men. "Mami Wata, a deity in Nigerian folklore is believed to be a woman with a half-human and halffish appearance with the ability to transform wholly into any form of her choice and often 
presented with long healthy hair, enviable beauty, and a dark yet appealing mysteriousness" (Face2Face Africa). "In the Caribbean and parts of South America, the deity is highly respected and feared with many stories around her identity. The role of the strikingly beautiful goddess is to provide spiritual and material healing to her worshippers, while also protecting their emotional and mental health and growth" (Face2FAce Africa). "Mama Wata is the protector of the water bodies and many Africans who find themselves in the Western world, specifically in the Caribbean and South America, the deity is said to have traveled with them on the Atlantic ocean protecting them and taking some of their pain to relieve them. She is said to have captured many slave ships that do not make it to their western destinations especially during the abolition of the slave trade" (Face2Face Africa). Mariá uses women in her photograph to pay homage to Mama Wata's legacy and to the dominant female energy that protects, guides, and destroys if need be.

Mariá Magdalena Campos-Pons' photograph focuses on the Atlantic Slave Trade and the journey to the New World, focusing on the traditions of West African culture in a subtle way that creates a strong emotional impact for the viewer so that they may never forget the history where we all collectively began the journey. 


\section{Works Cited}

Fanon, Frantz. Black skin, white masks. London: Paladin, 1970.

"Mami Wata, the Most Celebrated Mermaid-like Deity from Africa Who Crossed over to the West." Face2Face Africa, 21 July 2018, face2faceafrica.com/article/mami-wata-themost-celebrated-mermaid-like-deity-from-africa-who-crossed-over-to-the-west.

Neimark, Philip John. The way of the Orisa: Empowering your life through the ancient African religion of Ifa. HarperSanFrancisco, 1993.

"Old Conflicts, New Expressions.” C\& AMÉRICA LATINA, amlatina.contemporaryand.com/editorial/old-conflicts-new-expressions/. 